PEPATUDZU: Media Pendidikan dan Sosial Kemasyarakatan p-ISSN: 2087-3476 | e-ISSN: 2541-5700

\title{
PENGARUH PENGGUNAAN MEDIA DAKON MATEMATIKA TERHADAP HASIL BELAJAR SISWA KELAS TINGGI SD DI KABUPATEN GOWA
}

\author{
Risnawati $^{1}$, Ari Wibowo' ${ }^{2}$ Bahar $^{3}$ \\ Prodi Pendidikan Matematika Universitas Sawerigading Makassar \\ e-mail: risnawatiunsa@gmail.com
}

\begin{abstract}
This study aims to determine the use of dakon media on the learning outcomes of high school students in Gowa Regency then to find out the significant effect of using media dakon on the mathematics learning outcomes of high school students in Gowa Regency. The approach used is a quantitative approach. The type of research conducted is True-Experimental Design, which is a sample used for experiments and control groups taken randomly from certain populations. The research variables consist of two, namely the dakon Media as the independent variable $(X)$ and Learning Outcomes as the dependent variable (Y). The research design used in this study was the Design Matching Pretest-Posttest Control Group Design. random sample research (Therandomized pretest-posttest control grouf design. The population in this study were all high school students in Gowa Regency, totaling 836 elementary schools. Data analysis technique used was to test hypotheses using t-test with independent samples test $t$ test The results of the study showed that the learning process using the mathematics media was effective, it was seen that there was a significant influence of the use of mathematics media media to the mathematics learning outcomes of high school students in Gowa Regency.
\end{abstract}

Keywords: dakon media, mathematics learning outcomes

\section{PENDAHULUAN}

Hasil belajar adalah penilaian pendidikan tentang kemajuan siswa dalam segala hal yang dipelajari di sekolah menyangkut pengetahuan, kecakapan atau keterampilan yang dinyatakan sesudah penilaian. Hasil belajar ini dijadikan pedoman atau bahan pertimbangan dalam menentukan kemampuan siswa

Menurut Mujiono (Sundayana, 2013 : 25) “dalam proses belajar mengajar terdapat empat komponen penting yang berpengaruh bagi keberhasilan belajar siswa yaitu bahan belajar, suasana belajar, media dan sumber belajar serta guru sebagai subyek pembelajaran. Media sebagai salah satu komponen yang penting dipilih berdasarkan tujuan dan bahan pembelajaran yang akan diajarkan. Sehingga guru harus mampu memilih media yang tepat untuk memotivasi siswa 
untuk belajar serta pesan yang akan disampaikan dapat tersampaikan dengan baik. Hal ini sejalan dengan pendapat hamalik (Arsyad, $2014:$ 19) mengemukakan bahwa "Pemakaian media pembelajaran dalam proses belajar mengajar dapat membangkitkan keinginan dan minat, membangkitkan rangsangan kegiatan belajar, bahkan membawa pengaruh-pengaruh psikologi terhadap siswa.

Media dakon matematika dapat dipakai untuk membantu anak belajar pada konsep bilangan prima dan menentukan bilangan prima, menentukan faktorfaktor pembagi suatu bilangan, menentukan kelipatan suatu bilangan, menentukan factor persekutuan atau kelipatan persekutuan dua bilangan atau lebih, serta mencari kelipatan persekutuan terkecil dan faktor persekutuan terbesar dari dua bilangan atau lebih. Permainan dakon matematika merupakan media pembelajaran yang merupakan hasil dari modifikasi salah satu permainan tradisional Indonesia yaitu congklak (Linguistika, 2011). Dakon atau congklak dimainkan dengan cara berpasangan saling berhadapan dengan papan dakon berada diantara pemain. Setiap pemain memiliki masing-masing satu lubang penampung dan beberapa lubang kecil lainnya. Oleh karena itu, pembelajaran dengan menggunakan media dakon matematika sangat penting untuk menjacapi keberhasil belajar siswa.

Menurut Gagne (Sadiman, $2012: 6$ ) mengemukakan bahwa "media adalah berbagai jenis komponen dalam lingkungan siswa yang dapat merangsangnya untuk belajar". Pendapat tersebut diperjelas oleh Briggs (Hamzah, 2014 : 122) bahwa "media adalah segala bentuk fisik yang dapat menyampaikan pesan serta merangsang peserta didik untuk belajar".

Dari beberapa penjelasan tersebut dapat simpulkan bahwa media adalah semua bentuk bantuan penyaluran pesan oleh pemberi pesan kepada penerima pesan.

Beberapa defenisi media pembelajaran menurut para ahli :

1. Arief S. Sadiman, dkk (2012), mengemukakan bahwa media berasal dari kata latin yang berarti perantara atau pengantar. Media adalah perantara antara pesan antara penerima dan pemberi pesan.

2. AECT, 1979 (Sadiman, $2012: 6$ ) mendefinisikan "media sebagai segala bentuk yang digunakan untuk proses penyaluran informasi".

Menurut Kemp dan Dayton (Asyad, 2014 : 25) mengemukakan manfaat penggunaan media sebagai berikut : (1) Penyampaian pelajaran menjadi lebih baku. Setiap pelajar yang melihat atau mendengar penyajian melalui media menerima pesan yang sama, (2) Pembelajaran bias lebih menarik. Media dapat diasosiasikan sebagai penarik perhatian dan membuat siswa tetap terjaga dan memperhatikan, (3) Pembelajaran menjadi lebih interaktif dengan diterapkannya belajar teori belajar dan prinsip-prinsip psikologis yang diterima dalam hal partisipasi siswa, umpan balik, dan penguatan, (4) Lama waktu pembelajaran yang diperlukan dapat dipersingkat karena kebanyakan media menggunakan 
waktu yang singkat dalam mangantarkan pesan, (5) Kualitas hasil belajar dapat ditingkatkan bilamana integrasi kata dan gambar sebagai media pembelajaran dapat mengkomunikasikan elemen-elemen pengetahuan dengan cara terorgaganisisr dengan baik, (6) Pembelajaran dapat diberikan kapan dan di mana diinginkan atau diperlukan terutama jika media pembelajaran dirancang untuk penggunaan secara individu, (7) Sikap positif siswa terhadap apa yang mereka pelajari dan terhadap proses belajar dapat ditingkatkan, (8) Peran guru dapat berubah kearah yang lebih positif, beban guru untuk menjelaskan berulang-ulang mengenai isi pembelajaran dapat dikurangi.

Dari pendapat tersebut disimpulkan bahwa manfaat media pembelajaran yaitu sebagai alat bantu guru dalam menyampaikan pesan dari sebuah mata pelajaran yang akan diajarkan.

a. Pengertian Belajar dan Hasil Belajar

Menurut Bruner (dalam Kristina, 2014) belajar Matematika adalah "Belajar mengenai konsep-konsep dan struktur-struktur matematika yang terdapat di dalam materi yang dipelajari, serta mencari hubungan antara konsepkonsep dan struktur-struktur Matematika itu"

Hal senada dengan pendapat Namawi (Susanto, 2013) menyatakan bahwa hasil belajar dapat diartikan sebagai tingkat keberhasilan siswa dalam mempelajari materi pelajaran di sekolah dan dinyatakan dalam skor yang diperoleh dari hasil tes mengenai sejumlah meteri pelajaran tertentu.

b. Faktor yang Mempengaruhi Hasil Belajar

Hasil belajar yang diperoleh setiap anak akan berbeda hal ini dipengaruhi oleh bebrapa faktor yaitu (Susanto, $2013: 12$ ) : Faktor Internal, dan Faktor Eksternal.

\section{METODE PENELITIAN}

Pendekatan yang digunakan pendekatan kuantitatif dan Jenis penelitian yang dilakukan adalah True-Experimental Design adalah sampel yang digunakan untuk eksperimen maupun kelompok kontrol diambil secara random dari populasi tertentu.

Populasi dalam penelitian ini adalah keseluruhan siswa kelas tinggi SD yang ada di Kabupaten Gowa yang berjumlah 836 sekolah dasar. Sifat dan karakteristik populasi ini sama (homogen) karena menggunakan kurikum yang sama. Sehingga yang dijadikan sampel dalam penelitian ini adalah siswa kelas tinggi SD Inpres Paccinongan Kabupaten Gowa sebanyak 26 orang. 
PEPATUDZU: Media Pendidikan dan Sosial Kemasyarakatan p-ISSN: 2087-3476 | e-ISSN: 2541-5700

Tabel 1. Desain matching pretest-posttest control group design.

\begin{tabular}{|l|c|c|c|}
\hline \multicolumn{1}{|c|}{ Kelompok } & Pretest & Treatment & Posttest \\
\hline Eksperimen & $\mathrm{O}_{1}$ & $\mathrm{X}_{1}$ & $\mathrm{O}_{2}$ \\
\hline Kontrol & $\mathrm{O}_{3}$ & $\mathrm{X}_{2}$ & $\mathrm{O}_{4}$ \\
\hline
\end{tabular}

Sedangkan Teknik Pengumpulan Data yang digunakan adalah observasi, Tes, Dokumentasi dengan Prosedur pengumpulan data Pretest (Tes diberikan sebelum perlakuan), Treatment (Peneliti memberikan perlakuan kepada kelas eksperimen dengan menggunakan media pembelajaran dakon matematika, dan Posttest (Tes diberikan setelah treatment (perlakuan).

Teknik Analisis Data yang digunakan adalah Analisis statistika inferensial digunakan untuk menguji hipotesis penelitian dengan menggunakan uji-t. Namun sebelum dilakukan pengujian hipotesis, terlebih dahulu dilakukan uji normalitas dan homogenitas. Pengujian normalitas yang digunakan adalah KolmogorovSmirnov untuk mengetahui apakah data yang mengikuti populasi berdistribusi normal.

\section{HASIL DAN PEMBAHASAN}

Berdasarkan hasil observasi Keterlaksanaan Proses Pembelajaran Dengan Menggunakan Media Dakon Matematika pada Mata Pelajaran Matematika, dapat disimpulkan bahwa pada pertemuan I proses pembelajaran yang dilaksanakan dengan menggunakan media dakon matematika diperoleh presentase tingkat keefektifan $70,9 \%$ berada pada kategori efektif. Sedangkan pada pertemukan II proses pembelajaran yang dilaksanakan diperoleh tingkat keefektifan 83,3\% yang berada pada kategori sangat efektif.

Tabel 2. Distribusi frekuensi dan presentase kategori hasil pretest kelas eksperimen dan kelas kontrol

\begin{tabular}{|c|c|c|c|c|c|}
\hline \multirow{2}{*}{ Skor } & \multirow{2}{*}{ Kategori } & \multicolumn{2}{|c|}{ Frekuensi Kelas } & \multicolumn{2}{c|}{ Presentase Kelas } \\
\cline { 3 - 6 } & & Eksperimen & Kontrol & Eksperimen & Kontrol \\
\hline $81-100$ & Sangat Baik & - & - & - & - \\
\hline $61-80$ & Baik & 8 & 5 & $26,67 \%$ & $16,67 \%$ \\
\hline $41-60$ & Cukup & 22 & 25 & $73,33 \%$ & $83,33 \%$ \\
\hline $21-40$ & Kurang & - & - & - & \\
\hline $0-20$ & Sangat Kurang & - & - & - & - \\
\hline \multicolumn{7}{|c|}{ Jumlah } & 30 & 30 & 100.00 & 100.00 \\
\hline
\end{tabular}


Berdasarkan tabel frekuensi dan presentase kategori diatas, dapat diketahui bahwa pretest kelas eksperimen tidak ada yang berada pada kategori sangat kurang, kurang dan sangat baik. Distribusi frekuensi dan presentase pretest kelas eksperimen berada pada kategori cukup dan baik.

Tabel 3. Distribusi frekuensi dan presentase kategori hasil posttest kelas eksperimen dan kelas kontrol

\begin{tabular}{|c|c|c|c|c|c|}
\hline \multirow{2}{*}{ Skor } & \multirow{2}{*}{ Kategori } & \multicolumn{2}{|c|}{ Frekuensi Kelas } & \multicolumn{2}{c|}{ Presentase Kelas } \\
\cline { 3 - 6 } & & Eksperimen & Kontrol & Eksperimen & Kontrol \\
\hline $81-100$ & Sangat Baik & 8 & - & $26,67 \%$ & - \\
\hline $61-80$ & Baik & 22 & 16 & $73,33 \%$ & $53,33 \%$ \\
\hline $41-60$ & Cukup & - & 14 & & $46,67 \%$ \\
\hline $21-40$ & Kurang & - & - & - & - \\
\hline $0-20$ & Sangat Kurang & - & - & - & - \\
\hline \multicolumn{2}{|c|}{ Jumlah } & 30 & 30 & 100.00 & 100.00 \\
\hline
\end{tabular}

Berdasarkan tabel frekuensi dan pengkategorian di atas, dapat diketahui bahwa pada kelas eksperimen tidak terdapat siswa yang memperoleh nilai dalam kategori sangat kurang, kurang, dan cukup, 22 siswa pada kategori baik dan selebihnya pada kategori baik sangat baik. Sedangkan pada kelas kontrol tidak terdapat siswa yang memperoleh nilai dalam kategori sangat kurang, kurang, 14 siswa pada kategori cukup, 16 siswa pada kategori baik, dan tidak terdapat siswa pada kategori sangat baik. Hal tersebut menandakan bahwa kelas eksperimen lebih baik dibandingkan kelas kontrol karena siswa yang memperoleh nilai terendah pada kelas eksperimen berada pada kategori baik sedangkan siswa yang memperoleh nilai terendah pada kelas kontrol berada pada kategori cukup.

\section{Hasil Uji Normalitas}

Uji normalitas dilakukan untuk mengetahui apakah data yang diperoleh berdistribusi normal atau tidak normal.

Tabel 4. Uji normalitas data pretest dan posttest kelas kontrol dan eksperimen

\begin{tabular}{|c|c|c|}
\hline \multicolumn{1}{|c|}{ Data } & Sig. Kolmogorov-Smirnov & Keterangan \\
\hline Pretest Kontrol & 0,190 & $0,190>0,05=$ normal \\
\hline Postest Kontrol & 0,200 & $0,200>0,05=$ normal \\
\hline
\end{tabular}


PEPATUDZU: Media Pendidikan dan Sosial Kemasyarakatan p-ISSN: 2087-3476 | e-ISSN: 2541-5700

\begin{tabular}{|l|c|c|}
\hline $\begin{array}{l}\text { Pretest } \\
\text { Eksperimen }\end{array}$ & 0,108 & $0,108>0,05=$ normal \\
\hline $\begin{array}{l}\text { Posttest } \\
\text { Eksperimen }\end{array}$ & 0,127 & $0,127>0,05=$ normal \\
\hline
\end{tabular}

Hasil Uji Homogenitas

Tabel 5. Hasil uji homogenitas pretest dan posttest kelas kontrol dan kelas eksperimen

\begin{tabular}{|l|c|c|}
\hline \multicolumn{1}{|c|}{ Data } & Signifikansi & Keterangan \\
\hline $\begin{array}{l}\text { Pretest Kontrol dan } \\
\text { Eksperimen }\end{array}$ & 0,611 & $0,611>0,05=$ homogen \\
$\begin{array}{l}\text { Postest Kontrol dan } \\
\text { Eksperimen }\end{array}$ & 0,162 & $0,162>0,05=$ homogen \\
\hline
\end{tabular}

Menunjukkan bahwa hasil uji homogenitas pretest kelas kontrol dan eksperimen maupun posttest kelas kontrol dan kelas eksperimen dikatakan homogen karena nilai signifikansinya lebih dari 0,05 . Setelah mendapatkan hasil uji homogenitas yang dilakukan selanjutnya adalah uji statistic parametrik karena syarat menggunakan uji parametric telah tercapai.

\section{Hasil Uji Hipotesis}

Tabel 6. Hasil uji hipotesis

\begin{tabular}{|l|c|c|}
\hline \multicolumn{1}{|c|}{ Data } & Asymp. Sig. (2-tailed) & Keterangan \\
\hline $\begin{array}{l}\text { Pretest Eksperimen } \\
\text { dan Kontrol }\end{array}$ & 0,779 & $0,779>0,05=$ normal \\
\hline
\end{tabular}

Berdasarkan tabel dapat dilihat bahwa uji $\mathrm{T}$ yang digunakan menggunakan nilai equal variances assumed karena nilai signifikansi lebih besar dari 0,05 maka dapat disimpulkan bahwa tidak ada perbedaan yang signifikan dari pretest kelas kontrol dan kelas ekperimen. Sedangkan Hasil Uji Independent Samples T-Test Posttest Kelas Kontrol dan Eksperimen 
Tabel 7. Hasil uji independent samples t-test posttest kelas kontrol dan eksperimen

\begin{tabular}{|l|c|c|}
\hline \multicolumn{1}{|c|}{ Data } & Asymp. Sig. (2-tailed) & Keterangan \\
\hline $\begin{array}{l}\text { Posttest Eksperimen } \\
\text { dan Kontrol }\end{array}$ & 0,000 & $0,000<0,05=$ normal \\
\hline
\end{tabular}

Selama proses pembelajaran berlangsung, siswa kelas eksperimen yang menggunakan media dakon matematika terlihat lebih tertarik dalam memperhatikan materi yang disampaikan oleh peneliti. Selain itu, siswa lebih cepat tanggap dalam pemahaman materi serta lebih aktif dalam pembelajaran dibandingkan dengan kelas kontrol. Adapun Gambaran Hasil Belajar Sebelum memberikan perlakuan pada kelas eksperimen terlebih dahulu diberikan pretest untuk memperoleh data awal pada kelas eksperimen. Setelah pemberian pretest selanjutnya diberikan perlakuan dengan menggunakan media dakon matematika. Setelah pemberian perlakuan selanjutnya yang dilakukan yaitu memberikan posttest untuk mengetahui hasil belajar siswa setelah diberikan perlakuan. Berdasarkan analisis deskriptif yang dilakukan diketahui bahwa hasil pretest dan posttest hasil belajar kelas eksperimen berada pada kategori baik dengan jumlah nilai rata-rata pada pretest yaitu 56,28 dan posttest yaitu 73,71 .

\section{Pengaruh Media Dakon Terhadap Hasil Belajar}

Berdasarkan hasil uji independen samples $t$ test yang telah dilakukan terhadap kelas eksperimen dan kontrol, diketahui bahwa terdapat perbedaan hasil belajar siswa. Perbedaan yang pertama yaitu perbedaan sebelum dan sesudah diberikan perlakuan berupa penggunaan media dakon matematika pada kelas eksperimen dan tidak pada kelas kontrol. Perbedaan selanjutnya yaitu perbedaan hasil belajar antara kelas yang melaksanakan pembelajaran menggunakan media dakon matematika dan hasil belajar kelas yang tidak menggunakan media dakon matematika.

Jika dilihat dari perbedaan sebelum dan sesudah pemberian perlakuan pembelajaran dengan media dakon matematika, diketahui bahwa terdapat peningkatan rata-rata hasil belajar pada kelas eksperimen yaitu 56,28 menjadi 73,71. Hal tersebut menujukkan bahwa terdapat perbedaan hasil belajar sebelum dan sesudah diberikan perlakuan. Jika ditinjaudari rata-rata hasil pretest dan posttest kelas kontrol diketahui bahwa mengalami peningkatan tetapi tidak sebesar pada kelas ekspeimen.

Selanjutnya ditinjau dari hasil belajar kelas eksperimen yang mendapatkan perlakuan penggunaan media dakon matematika dan kelas kontrol. Pada hasil pengujian yang telah dilakukan dimana hasil pretest kelas eksperimen dan kelas kontrol diketahui bahwa tidak memiliki perbedaan yang signifikan dengan nilai signifikansi yang lebih dari 0,05 yaitu sebesar 0,779 . Sedangkan nilai 
rata-rata hasil posttest kelas eksperimen dan kelas kontrol dengan nilai signifikansi yang berada dibawah 0,05 yaitu sebesar 0,000 diketahui bahwa terdapa perbedaan yang signifikan. Hasil penelitian tersebut menunjuukan bahwa terdapat perbedaan yang signifikan dari kelas yang mendapatkan perlakuan penggunaan media dakon matematika dengan yang tidak menggunakan media dakon matematika.

Oleh karena itu hasil penelitian menunjukkan bahwa penggunaan media dakon matematika dapat mempengaruhi hasil belajar siswa hal tersebut telihat meningkatkannya minat belajar siswa, keaktifan siswa dalam belajar, selain itu pembelajaran menjadi lebih menyenangkan dengan penggunaan media dakon matematika terhadap siswa kelas tinggi SD Inpres Paccinongan Kabupaten Gowa.

\section{SIMPULAN}

Berdasarkan pembahasan yang dilakukan disimpulkan seperti berikut:

1. Media dakon matematika memberikan dampak yang positif terhadapa hasil belajar siswa, lebih efektif digunakan dalam pembelajaran hal tersebut terlihat perbedaan dari nilai rata-rata pretest dan posttest kelas eksperimen dan kontrol, hasil belajar siswa pada kelas eksperimen meningkat dibandingkan dengan hasil belajar siswa kelas kontrol.

2. Penggunaan Media dakon matematika berpengaruh terhadap hasil belajar siswa kelas tinggi SD Inpres Paccinongan Kabupaten Gowa. Hal tersebut terlihat pada perbedaan hasil belajar siswa antara kelas yang menggunakan media dakon matematika dan tidak menggunakan media dakon matematika dengan nilai signifikan uji t hasil posttest kelas eksperimen dan kontrol yang lebih kecil dari 0,05 yaitu 0,031 yang artinya berbeda secara signifikan.

\section{SARAN}

1. Bagi guru, agar menggunakan media pada saat pembelajaran matematika terkhusus media dakon matematika sebagai salah satu alternatif media yang dapat meningkatkan pemahaman siswa dalam pembelajaran matematika.

2. Bagi siswa, diharapkan selalu aktif dalam proses pembelajaran matematika, sehingga minat belajar tidak pernah turun untuk selalu belajar.

3. Bagi Kepala Sekolah SD Inpres Paccinongan Kabupaten Gowa dapat menjadikan penelitian ini sebagai motivasi dalam pengembangan media pembelajaran khususnya dalam pembelajaran matematika.

4. Bagi peneliti selanjutnya, penelitian ini dapat dijadikan sebagai bahan referensi. 


\section{DAFTAR PUSTAKA}

Arsyad, Azhar. 2014. Media Pembelajaran. Jakarta. RajaGrafindo Persada.

Aspriliana,Rizkia.2018. Pengaruh Media Dakon Bilangan Terhadap Hasil Belajar FPB dan KPK Siswa SDN 34 Pontianak. JIPP, Vol. 7 (3) :6-7.

Gafur, Abdul. 2012. Desain Pembelajaran. Yogyakarta. Penerbit Ombak

Hamzah, Nina Lamatenggo. 2014. Teknologi Komunikasi dan Informasi Pembelajaran. Jakarta. Bumi Aksara.

Hidayat, Asep. 2016. Pengaruh Penggunaan Alat Peraga Dakon Matematika (Dakota) Terhadap Hasil Belajar Matematika Siswa. Skripsi. Jakarta. Fakultas Ilmu Tarbiyah dan Keguruan. Universitas Islam Negeri Syarif Hidayatullah.

Kristina Mardiana. 2014.Peningkatan Aktivitas Dan Hasil Belajar Siswa Menggunakan Dakon Bilangan Kelas IV SDN 06 jurnal pendidikan dan pembelajaran UNTAN. https://www.neliti.com/id/journals/jurnalpendidikan-dan-pembelajaran-untan

Kunandar. 2013. Penilaian Autentik. Jakarta. RajaGrafindo Persada.

Linguistika,Yulia dan Ikfan Febriyana. 2011. Permainan Dakonmatika Sebagai Media Pembelajaran Matematika Topik Faktor Persekutuan Terbesar (FPB) dan Kelipatan Persekutuan Terkecil (KPK) bagi Siswa Sekolah Dasar. Makalah. Disajikan dalam Seminar Nasional Matematika dan Pendidikan Matematika. Yogyakarta. 3 Desember 2011.

Mahmud. 2011. Merode Penelitian Pendidikan.Bandung. Pustaka Setia.

Mardiana, Kristina. 2014. Peningkatan Akrivitas dan Hasil Belajar Siswa Menggunakan Dakon Bilangan Kelas IV SDN 06. Skripsi. Pontianak. Universitas Tajung Pura.

Nunu Mahnun. 2012. Kajian terhadap Langkah-langkah Pemilihan Media dan Implementasinya dalam Pembelajaran. Jurnal Pemikiran Islam; Vol. 37, No. 1 Januari-Juni 2012. http://ejournal.uinsuska.ac.id/index.php/Anida/issue/view/86/showToc

Purwanto, Ngalim. 2010. Prinsip dan Teknik Evaluasi Pengajaran. Bandung. Remaja Rosdakarya

Sadiman Arief, dkk. 2012. Media Pendidikan. Jakarta. Rajagrafindo Persada.

Siregar,syofian. 2014. Statistik Parametrik Untuk Penelitian Kuantitatif. Jakarta. Bumi aksara.

Sukardi. 2013. Metodologi penelitian pendidikan. Jakarta. Bumi Aksara 